\title{
PAPILLOMA DAN KARSINOMA SINONASAL
}

\author{
Rizki Hanriko', Muhartono \\ ${ }^{1,2}$ Bagian Anatomi, Histologi dan Patologi Anatomi, FK UNILA \\ Email: rizki.hanriko@gmail.com
}

\begin{abstract}
Pappiloma and Sinonasal Tumors. Sinonasal papilloma is rare, only $0.5-4 \%$ of sinonasal tumors with aetiopathogenesis has not known yet. Sinonasal carcinoma is a rare malignancy, and the most common types are squamous cell carcinoma (SCC). Malignant transformation of papilloma is very low, which inverted type were reported about 2-27\%, with the development of papilloma into carcinoma was approximately 63 months (6 months-13 years). Prior study showed the malignant transformation in $11 \%$ of recurrences inverted papilloma, which were $7 \%$ syncronous and $3.6 \%$ metachronous SCC. The unilateral inverted papilloma with sinonasal squamous cell carcinoma were usually occured in the elderly. Some factors to consider in malignant transformation of papilloma were recurrence, atypical features and HPV. Smoker, large tumor and lesion in the frontal sinus area were had a tendency to recurrence. Malignancy were associated with bone invasion, bilateral inverted papilloma, squamous cell hyperplasia, presence of three types of epithelial cells (squamous metaplasia, squamous mature and cylindrical cell), heavy hyperkeratosis, mitotic index $\geq 2 / \mathrm{HPF}$, the absence of polyps inflammation, the number of plasma cells, low of eosinophils and neutrophils absent.
\end{abstract}

Keywords: Tumors, Pappiloma, Sinonasal, Tranformation

\begin{abstract}
Abstrak: Papiloma dan Karsinoma Sinonasal. Papilloma sinonasal jarang ditemukan yaitu hanya $0,5-4 \%$ dari tumor sinonasal dengan etiopatogenesis belum diketahui pasti. Karsinoma sinonasal merupakan keganasan yang jarang terjadi dengan jenis yang paling sering ditemukan adalah Squamous cell carcinoma (SCC). Transformasi keganasan pada papilloma sangat rendah, yaitu tipe inverted dilaporkan insiden sisekitar 2-27\%, dengan perkembangan papilloma menjadi karsinoma sekitar 63 bulan (6 bulan-13 tahun). Dari beberapa penelitian didapatkan adanya transformasi keganasan pada 11\% dari rekurensi inverted papilloma, yaitu 7\% syncronous SCC dan 3,6\% metachronous SCC. Pada inverted papiloma yang unilateral dengan karsinoma sel skuamous sinonasal umumnya terjadi pada usia lanjut. Beberapa faktor yang perlu diperhatikan dalam transformasi papilloma menjadi keganasan adalah rekurensi, gambaran atipia dan etiologi HPV. Perokok, besar tumor dan lokasi lesi di daerah sinus frontal memiliki kecenderungan untuk rekurensi berulang. Keganasan berhubungan dengan invasi ke tulang, inverted papilloma bilateral, sel skuamous hiperplasia, adanya ketiga tipe sel epitel (metaplasia skuamosa, skuamosa matur dan silindris), hyperkeratosis berat, indeks mitotik $\geq 2 / \mathrm{HPF}$, tidak adanya polip peradangan, banyaknya sel plasma, rendahnya eosinofil dan absennya netrofil.
\end{abstract}

Kata kunci: Karsinoma, Papilloma, Sinonasal, Transformasi

Sinonasal merupakan istilah untuk pengelompokan rongga hidung dan sinus paranasal. Mukosa pada daerah ini dilapisi epitel gepeng berlapis dan kolumner Pseudostritified (Barnes et al., 2005; Rosai, 2011).

Berdasarkan WHO, papilloma sinonasal dibagi menjadi inverted papilloma, oncocytic papilloma dan exophytic papilloma, sedangkan karsinoma sinonasal dibagi menjadi karsinoma sel skuamosa (squamous cell carcinoma, SCC), adenokarsinoma, lymphoepithelial carcinoma dan undifferentiated carcinoma (Barnes et al., 2005).

Papilloma sinonasal merupakan tumor yang jarang ditemukan yaitu hanya $0,5-4 \%$ dari tumor sinonasal (Sadeghi and Al-Sebeih, 2011). Etiologi dan patogenesis papilloma sinonasal belum diketahui pasti. Karsinoma sinonasal merupakan keganasan yang jarang terjadi yaitu kurang dari $1 \%$ dari seluruh kejadian tumor ganas dan sekitar $3 \%$ dari seluruh keganasan yang mengenai kepala dan leher (Barnes et al., 2005; Antonio Cardesa and Slootweg, 2006). SCC adalah jenis yang paling sering ditemukan pada sinonasal. Faktor resiko yang memiliki hubungan erat dengan kejadian karsinoma sinonasal adalah perokok dan paparan dari pekerjaan (occupational exposure) (Barnes et al., 2005; Antonio Cardesa and Slootweg, 2006; Rosai, 2011; Sadeghi and Al-Sebeih, 2011).

Penyebab papilloma sinonasal masih belum jelas. Kemungkinan disebabkan alergi, sinusitis kronis, pulisi udara dan infeksi human 
papilloma virus (HPV). Sebagian besar karsinoma sel skumosa terjadi pada daerahdaerah yang terpapar sinar matahari, dapat pula terjadi pada mukosa yang ulserasi atau iritasi kronik, dan trauma.(Barnes et al., 2005; Sadeghi and Al-Sebeih, 2011).

Etiologi karsinoma sinonasal memiliki hubungan erat dengan faktor resiko termasuk diantaranya rokok, paparan dari pekerjaan seperti pada pekerja tambang nikel dan kromium, pekerja tekstil, kulit dan kayu, dan riwayat menderita papilloma sinonasal dengan infeksi HPV.(Barnes et al., 2005; Antonio Cardesa and Slootweg, 2006; Rosai, 2011; Sadeghi and AlSebeih, 2011).

Paparan kronis karsinogen dan inflamasi dapat menyebabkan kerusakan gen. Akumulasi perubahan-perubahan genetik dapat menimbulkan lesi premalignant yang akhirnya dapat berkembang menjadi karsinoma (Barnes et al., 2005).

Inhalasi partikel debu kayu berukuran lebih dari $5 \mu \mathrm{m}$ menyebabkan ia terperangkap dalam mukosa konka media dan ethmoid, mengakibatkan melemahnya atau terganggunya fungsi silia pada sel-sel sinonasal. Paparan dan iritasi yang lama pada mukosa memungkinkan terjadi efek karsinogenik melalui inflamasi kronik sehingga terjadi perubahan seluler berupa metaplasia dan displasia Hal ini diduga sebagai mekanisme penting dalam inisiasi dan progresi menjadi massa tumor (Barnes et al., 2005; Thompson, 2011). Diperlukan waktu yang lama (40-43 tahun) untuk terjadi perubahan sejak pertama kali terpapar dengan debu kayu hingga menjadi karsinoma (Leon Barnes, 2002).

Terapi yang direkomendasikan adalah eksisi luas pada papilloma dan kombinasi antara pembedahan/ reseksi dan radiasi untuk karsinoma. Prognosis pada penyakit ini tergantung pada stadium dan letak tumor (Rosai, 2011; Sadeghi and Al-Sebeih, 2011).

\section{PEMBAHASAN}

Transformasi keganasan pada papilloma sangat rendah dimana tipe inverted yang paling sering terjadi. Pada tipe inverted dilaporkan insidensi menjadi keganasan sekitar 2-27\%, dengan perkembangan papilloma menjadi karsinoma sekitar 63 bulan (6 bulan-13 tahun) (Sadeghi and Al-Sebeih, 2011).

Dari beberapa penelitian didapatkan adanya transformasi keganasan pada $11 \%$ dari rekurensi inverted papilloma dimana $7 \%$ syncronous SCC dan 3,6\% metachronous SCC.
Pada inverted papiloma yang unilateral dengan karsinoma sel skuamous sinonasal umumnya terjadi pada usia lanjut (Weedon, 2010; Sadeghi and Al-Sebeih, 2011).

Tidak terdapat signifikansi hubungan papilloma dengan karsinoma, tetapi hubungan papilloma dengan keganasan dapat dijelaskan melalui 3 cara (Rosai, 2011; Thompson, 2011):

Keganasan karsinoma berkembang setelah eksisi papilloma dengan/tanpa rekuren (3\%).

Adanya fokal invasive carcinoma bersamaan dengan papilloma saat papilloma pertamakali di eksisi (3\% dan prognosis baik).

Kejadian tumor memiliki gambaran yang sama dengan papilloma tapi dengan gambaran keganasan sitologi yang lemah $(25 \%$ dan prognosis jelek).

Beberapa faktor yang perlu diperhatikan dalam transformasi papilloma menjadi keganasan adalah rekurensi, gambaran atipia dan etiologi HPV.

Papilloma sinonasal mempunyai kecenderungan untuk rekuren terutama tipe inverted. Angka kejadian rekurensi papiloma 0$78 \%$, paling sering akibat reseksi terbatas/ yang tidak optimal dan transformasi keganasan mencapai 11\% (Barnes et al., 2005; Kumar, Abbas and Aster, 2015). Pada beberapa penelitian HPV ditemukan pada papiloma dan sel normal sekitarnya, oleh sebab itu disarankan untuk eksisi yang luas termasuk sel yang normal untuk mencegah rekurensi dan transformasi keganasan. Sekali papiloma rekuren maka rekurensi berikutnya mencapai 58\%. Perokok, besar tumor dan lokasi lesi di daerah sinus frontal memiliki kecenderungan untuk rekurensi berulang. $\mathrm{R}$ Overekspresi Ki67, loss dari basal cell keratin 14 dan peningkatan level fascin dapat digunakan sebagai petanda rekurensi inverted papilloma (Kumar, Abbas and Aster, 2015).

HPV merupakan virus DNA yang terbukti menyebabkan neoplasma pada keganasan serviks dengan viral onkoprotein E6 dan E7 yang menyebabkan degradasi p53 dan pRB sehingga berperan pada tumorigenesis (Rosai, 2011; Kumar, Abbas and Aster, 2015).

Human papilloma virus (HPV) seringkali dilaporkan berhubungan dengn papilloma nasal. Beberapa penelitian menunjukkan adanya DNA HPV pada 50-100\% exophytic papilloma dan 0$86 \%$ pada inverted papilloma. Adanya gangguan pada p53 merupakan faktor risiko transformasi keganasan. Overekspresi p53 terdapat pada papilloma dengan displasia berat dan papilloma dengan karsinoma. Peningkatan derajat displasia berhubungan dengan infeksi HPV 6/11 dan 16/18 (Weedon, 2010; Sadeghi and Al-Sebeih, 2011; 
Thompson, 2011).

Pada penelitian oleh Kanicka dkk ditemukan bukti over imunoekspresi p16INK4a dan siklin D1 dan imunoekspresi yang rendah pada p21waf/cip1 dan p53 pada inverted papilloma yang disebabkan HPV. Hal ini bisa dijelaskan melalui siklus sel. Siklus sel dikontrol oleh famili Siklin, siklin dependen kinase (CDK) dan inhibitornya (CDKi) dengan aktivasi dan inaktivasi fosforilasi. Siklin D1 berfungsi mengatur transisi dari fase G1 ke fase S yang mencapai level maksimum dan membentuk kompleks kinase fungsional dengan CDK4,6 selama fase mid-G1. CDK/kompleks siklin yang aktif diatur melalui ikatan dengan CDKi p16INK4a dan p21waf1/cip1 dan menghambat siklus sel dari fase G1 ke S. P16INK4a berfungsi menghambat CDK yang merangsang fosforilasi pRB untuk melepaskan faktor transkripsi E2F pada transisi G1-S. Sama seperti protein p16, HPV akan mengikat pRB melalui onkoprotein E7 dan melepaskan E2F dengan akibat overekspresi p16. Protein $\mathrm{p} 21 \mathrm{waf1} / \mathrm{cip} 1$ normal terdapat pada sel dengan kompleks siklin, CDK dan proliferating cell nuclear antigen. P21wafl/cip1 merupakan mediator p53, diduga sebagai tumor supressor gen (Kanicka, Danilewicz and Danilewicz, 2011).

Beberapa penelitian menyebutkan adanya gambaran atipia pada papiloma yang merupakan predisposisi untuk rekuren walapun tidak ada data yang signifikan menunjukkan adanya hubungan antara derajat atipia, indeks mitotik dan rekurensi ataupun transformasi keganasan. Keganasan berhubungan dengan invasi ke tulang, inverted papilloma bilateral, sel skuamous hiperplasia, adanya ketiga tipe sel epitel (metaplasia skuamosa, skuamosa matur dan silindris), hiperkeratosis berat, indeks mitotik $\geq 2 / \mathrm{HPF}$, tidak adanya polip peradangan, banyaknya sel plasma, rendahnya eosinofil dan absennya netrofil (Weedon, 2010; Kumar, Abbas and Aster, 2015).

Adanya HPV pada inverted papilloma dapat dijadikan prediksi untuk transformasi ke arah keganasan. Faktor petanda lain yang dapt dijadikan sebagai prediksi keganasan adalah overekspresi p21 dan p53 serta peningkatan level fascin yang normalnya ditemukan rendah di epitel. Peningkatan ekspresi epithelial growth factor receptor dan TGF- $\alpha$ berhubungan dengan kejadian awal karsinogenesis dari inverted papilloma. Pada inverted papilloma juga ditemukan korelasi yang signifikan antara ekspresi topoisomere II- $\alpha$ dan Ki67 sebagai indikator faktor prognostik kemungkinan transformasi keganasan (Mirza et al., 2007; Anari and Carrie, 2010; Kumar, Abbas and Aster, 2015).

Terapi untuk karsinoma sinonasal adalah kombinasi antara pembedahan dan terapi radiasi (Rosai, 2011; Sadeghi and Al-Sebeih, 2011). Prognosis pasien karsinoma sel skuamous sinonasal dengan/ tanpa inverted papilloma berbeda secara signifikan dimana pada synchronous carcinoma prognosisnya lebih baik dengan 5YSR mencapai $70 \%$ sedangkan yang tanpa inverted papiloma 5YSR hanya 30\% (Weedon, 2010; Kumar, Abbas and Aster, 2015).

\section{SIMPULAN}

Sinonasal merupakan istilah untuk pengelompokan rongga hidung dan sinus paranasal. Papilloma sinonasal merupakan tumor yang jarang ditemukan yaitu hanya $0,5-4 \%$ dari tumor sinonasal. Etiologi dan patogenesis papilloma sinonasal belum diketahui pasti. Karsinoma sinonasal merupakan keganasan yang jarang terjadi. Faktor resiko yang memiliki hubungan erat dengan kejadian karsinoma sinonasal adalah perokok dan occupational exposure.

Transformasi papilloma sinonasal menjadi karsinoma sinonasal baik synchronous maupun metachronous carcinoma dihubungkan dengan kejadian rekurensi, atipia dan displasia serta persamaan etiologi akibat HPV, sehingga perlu terapi dan follow up pasien dengan lebih baik dan hati-hati.

\section{DAFTAR PUSTAKA}

Anari, S. and Carrie, S. 2010. Sinonasal Inverted Papilloma: Narrative Review. J Laryngol otol, 124, pp. 705-715.

Antonio Cardesa and Slootweg, P. 2006. Pathology of the Head and Neck. Germany: Springer.

Barnes, L., Eveson, J. W., Reichart, P. and

Sidransky, D. 2005. Pathology and Genetics of Head and Neck Tumours. WHO Classification of Tumour, (9), pp. 163-175. doi: 10.1016/j.urology.2004.09.048.

Kanicka, O., Danilewicz, M. and Danilewicz, M. 2011. Effect of Human Papillomavirus on 
Cell Cycle Related Protein p16INK4A, p21waf1/cip1, p53 dan cyclin D1 in Sinonasal Inverted Papilloma and Laryngeal. An Insitu Hybridization Study Carcinoma. Folia Histochem Cytobiol, 49(1), pp. 34-40.

Kumar, V., Abbas, A. K. and Aster, J. C. 2015. Robbin's Basic Pathology. 9th edn. New York: Elsevier.

Leon Barnes. 2002. Schneiderian Papillomas and Nonsalivary Glandular Neoplasm of the Head and Neck. Mod Pathol, 15(3), pp. 279-297.

Mirza, S., Bradley, P., Acharya, A., Stacey, M. and Jones, N. 2007. Sinonasal Inverted Papillomas: Reccurence and Synchronous and Metachronous Malignancy. J Laryngol Otol, 121, pp. 857-864.

Rosai, J. 2011. Respiratory Tract', in Rosai \& Ackerman's Surgical Pathology. 9th edn. Toronto: Mosby, pp. 294-303.

Sadeghi, N. and Al-Sebeih, K. 2011. Sinonasal Papillomas', medscape refference. Available at: http://emedicine.medscape.com/article/862 677-overview.

Thompson, L. D. 2011. Sinonasal Carcinomas. Current Diagnostic Pathology, 12(1), pp. 40-53. Available at: http://sciencedirect.com/science/article/pii/ s0968605305001079.

Weedon, D. 2010. Weedon's Skin Pathology. 